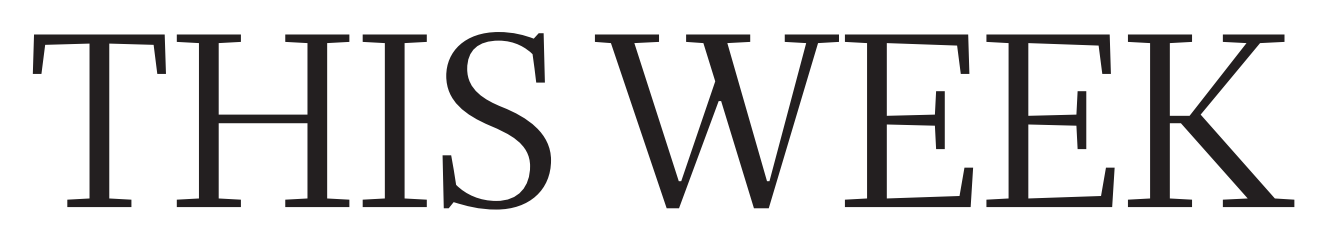

EDITORIALS

ASBESTOS No excuse for countries failing to ban this killer mineral $\mathbf{p . 8 6 8}$
WORLD VIEW Clinical pharmacology is dead. Long live TMAT $\mathbf{p . 8 6 9}$
SNAKE FOOD Southpaw snails prove hard to swallow p.870

\title{
Response required
}

\section{Blogs and online comments can provide valuable feedback on newly published research. Scientists need to adjust their mindsets to embrace and respond to these new forums for debate.}

Y ou may have seen claims that scientists at NASA have discovered a bacterium that can replace the phosphorus in its DNA with arsenic. You may have heard that this could help the hunt for aliens. You may even have heard that the 'arsenic bacterium' is itself an alien. What you will not have seen or heard is a detailed response from NASA and the scientists involved to online criticism of their work. In the face of worldwide attention on their paper (F. WolfeSimon et al. Science doi:10.1126/science.1197258; 2010), which NASA and the team deliberately courted, the researchers have stuck their heads in the digital sand.

In response to the arsenic bacterium claims, bloggers and researchers raised serious and thoughtful reservations about the paper's methodology and findings. But the authors say that they will not engage with these critics, or with science journalists drawn to the controversy, because such discussion should be moderated in the peer-reviewed literature. Meanwhile, they are urging other scientists to work to replicate their results - a process that will take many months. "We are not going to engage in this sort of discussion," Felisa Wolfe-Simon, the paper's lead author and a NASA astrobiology research fellow at the US Geological Survey in Menlo Park, California, told one Nature reporter, "Any discourse will have to be peer-reviewed in the same manner as our paper was, and go through a vetting process so that all discussion is properly moderated."

Purists who hold peer review as the casting vote in such debates will read her words with approval. But the problem is that WolfeSimon's reticence is the polar opposite of the fanfare with which NASA trailed her discovery to the public. In an advance press advisory on 29 November, NASA trumpeted an "astrobiology finding that will impact the search for evidence of extraterrestrial life". At a press conference to coincide with the paper's publication, the authors reported a more down-to-Earth, but nonetheless radical, discovery, claiming that an arsenic-tolerant bacterium had rewritten the rules of life as we know them.

Such claims were always likely to bring intensive scrutiny, especially as many scientists think that NASA has form for making extravagant claims in the field of astrobiology. Within two days of the paper appearing, Rosie Redfield, a microbial geneticist at the University of British Columbia in Vancouver, Canada, published a long and detailed critique of what she described as the paper's methodological shortcoming on her blog (go.nature.com/ddesjw). She was one of several researchers who used their blogs to question whether the paper's data supported its claims. It was at this point that the authors, previously happy to promote their findings, refused to answer further questions and retreated behind the walls of peer review.

Formal peer review does give criticized authors time to think critically and carefully, and it is a good way to filter out rubbish. But in this case, much of the criticism was already coming from the researchers' peers. And it should be remembered that peer review as conducted by journals roadmap, capacity is as essential as funding.

\section{$\mathrm{T}$} To win a national bid to host a new European research facility is, for academics, akin to being chosen to hold the Olympic Games. The warm glow of prestige is matched by the flow of hard cash to regenerate land and communities, while the rush of the best scientific minds to the new equipment can give a major boost to national research performance.

So the Czech Republic, Hungary and Romania are rightly proud to have beaten France and the United Kingdom to jointly host the $€ 800$-million (US\$1-billion) Extreme Light Infrastructure (ELI), a 